\title{
Advanced Glycation End-Product Pentosidine Is Not a Relevant Marker of Disease Activity in Patients with Rheumatoid Arthritis
}

\author{
L. ŠENOLT, M. BRAUN, J. VENCOVSKÝ, L. ŠEDOVÁ, K. PAVELKA \\ Institute of Rheumatology, Charles University, First Medical Faculty, Prague, Czech Republic
}

Received November 2, 2006

Accepted January 15, 2007

On-line available February 8, 2007

\begin{abstract}
Summary
Advanced glycation end-product (AGE) pentosidine has previously been demonstrated in different tissues and body fluids. It was suggested as a novel marker for evaluating the pathologic activity in rheumatoid arthritis (RA). In this study we analyzed the relation between pentosidine and markers of inflammation, cartilage turnover, immune response, and disease status of RA. Using HPLC, we analyzed pentosidine in serum and synovial fluid from 39 patients with RA and in serum from 38 healthy controls. Cartilage oligomeric matrix protein (COMP) and antibodies to CCP (anti-CCP) were measured by ELISA. Clinical disease status was assessed by Disease Activity Score 28 (DAS 28) and functional status by Health Assessment Questionnaire (HAQ). We demonstrated significantly higher serum levels of pentosidine in RA patients in comparison with controls. Pentosidine in serum significantly correlated with pentosidine in synovial fluid. Serum pentosidine levels were associated with erythrocyte sedimentation rate $(p<0.03)$ but not with CRP, COMP, anti-CCP antibodies, DAS 28, or HAQ. In contrast to previous studies, we could not show any correlation of pentosidine levels with inflammatory status, clinical disease activity, markers of immune response, or cartilage breakdown. However, AGEs can be suggested as important players participating in joint destruction rather than markers of disease activity.
\end{abstract}

\section{Key words}

Pentosidine $\bullet$ Advanced glycation end-product (AGE) • Rheumatoid arthritis $\bullet$ Cartilage oligomeric matrix protein $(\mathrm{COMP}) \bullet$ Anti-CCP antibodies

\section{Introduction}

Pentosidine represents one of the wellcharacterized members of advanced glycation endproducts (AGEs) that are formed during spontaneous reaction of pentoses with free amino groups such as lysine and arginine. It is apparent that beside nonenzymatic glycation, oxidative stress, and inflammatory processes significantly accelerate the formation of AGEs. Pentosidine has been found in a variety of human tissues where it forms both adducts and intermolecular crosslinks, which are suggested to be the link between tissue damage and the aging process (Sell and Monnier 1989). AGEs accumulation is associated with several age-related diseases including diabetes mellitus (Monnier et al. 1992, Dyer et al. 1993), renal failure (Miyata et al. 1996), or 
Alzheimer disease (Smith et al. 1994).

The highest accumulation of AGEs was observed in tissues with long-lived proteins such as in articular cartilage collagen (Takahashi et al. 1994, Verzijl et al. 2000). This phenomenon is proposed to be responsible for the modification of both biochemical and mechanical properties of the hyaline cartilage during aging (Verzijl et al. 2003). In addition to articular cartilage (Takahashi et al. 1994), higher accumulation of AGEs has also been detected in synovial tissue (Drinda $e t$ al. 2002), serum, urine, and synovial fluid in patients with rheumatoid arthritis (RA) (Takahashi et al. 1997, Miyata et al. 1998, Chen et al. 1998, 1999). RA represents a chronic inflammatory autoimmune disease affecting joints as well as extraarticular tissues. Cartilage destruction and bone erosion, the main phenomena of RA pathology, are induced by hyperplastic synovium containing activated synovial fibroblasts and immune cells (Karouzakis et al. 2006, Stanczyk et al. 2006). These cells can trigger production of reactive oxygen species thereby increasing oxidative stress that is supposed to contribute to the pathogenesis of RA (Hitchon and El-Gabalawy 2004). It represents a vicious cycle contributing to higher levels of pentosidine in joint tissues and body fluids in RA patients as mentioned above. Moreover, higher levels of pentosidine in body fluids of RA patients correlated significantly with inflammatory markers including C-reactive protein (CRP), erythrocyte sedimentation rate (ESR), white blood cell count, and platelet count, as well as with activity of the disease, making pentosidine a potential novel RA biomarker (Takahashi et al. 1997, Miyata et al. 1998, Chen et al. 1998, 1999).

Cartilage oligomeric matrix protein (COMP) is a non-collagenous glycoprotein that is supposed to be a marker of cartilage destruction (Neidhart et al. 1997). Its increased levels in the serum are good prognostic markers for further rapid joint destruction in patients with early RA (Forslind et al. 1992). COMP is decreased in RA patients treated with anti-TNF- $\alpha$ (Crnkic 2003). In recent years, many studies focused on the analysis of anti-cyclic citrullinated peptides (anti-CCP) that have been suggested to be of diagnostic and prognostic benefit for patients with RA (Vencovsky et al. 2003, Raza et al. 2005). Anti-CCP antibodies might become a new diagnostic criterion that can discriminate between RA and non-RA patients in the early onset of the disease.

We have recently shown that higher serum pentosidine levels correlated significantly with marker of cartilage destruction COMP in synovial fluid from patients with knee osteoarthritis (OA) (Šenolt et al. 2005). We therefore explored in the present study the relationship of pentosidine with disease activity status, markers of inflammation, cartilage destruction, and antiCCP antibodies in patients with established and active RA.

\section{Methods}

\section{Patients}

Thirty-nine patients with active RA ( 32 females and 7 males, mean age 52.8 years), regularly followed at the Institute of Rheumatology in Prague, Czech Republic, were enrolled to this study. Patient's characteristics are given in Table 1. All patients fulfilled the criteria of the American College of Rheumatology (ACR) for the diagnosis of RA (Arnett et al. 1988). Synovial fluid was collected at the time of knee joint effusion as a part of the therapeutic regimen. Blood samples were withdrawn at the time of synovial fluid aspiration. After collection, serum and synovial fluid samples were stored at $-20{ }^{\circ} \mathrm{C}$. The control group, described in our previous study (Šenolt et al. 2005), included 38 healthy volunteers ( 23 females and 15 males, mean age 58.3 years) without a history of joint disorders who agreed with blood withdrawal. Individuals with diabetes mellitus and/or abnormal serum creatinine or renal disorder were not included in this study. All individuals signed informed consents and the study was approved by the local Ethics Committee.

\section{Clinical disease activity assessment}

Clinical disease activity of RA patients was assessed by the Disease Activity Score 28 calculated according to the DAS 28 formula with four variables $[0.56 \sqrt{ }$ (number of tender joints) $+0.28 \sqrt{ }$ (number of swollen joints) $+0.7 \mathrm{Ln}$ (ESR) +0.014 (patient's assessment of disease activity)] (Prevoo et al. 1995). The functional status of RA patients was assessed by the Health Assessment Questionnaire (HAQ) (Ramey et al. 1992). All RA patients were treated with a low dose of glucocorticoids and disease modifying drugs (DMARDs) and none of them was treated with biologically drugs.

\section{High performance liquid chromatography}

As described earlier (Špaček and Adam 2002), pentosidine was measured by the high performance liquid chromatography (HPLC) combined with sensitive 
Table 1. Characteristics of patients with rheumatoid arthritis (RA) and control individuals.

\begin{tabular}{|c|c|c|c|}
\hline Characteristics & $\operatorname{RA}(n=39)$ & $\begin{array}{l}\text { Control } \\
\text { s }(\mathbf{n}=38)\end{array}$ & $\mathbf{p}$ \\
\hline Age (years) & $52.8 \pm 2.3$ & $58.9 \pm 1.6$ & NS \\
\hline Sex (male/female) & $7 / 32$ & $15 / 23$ & - \\
\hline $\begin{array}{l}\text { Disease duration } \\
\text { (years) }\end{array}$ & $9.6 \pm 1.1$ & - & - \\
\hline DAS 28 score & $5.6 \pm 0.2$ & - & - \\
\hline$H A Q$ & $1.2 \pm 0.1$ & - & - \\
\hline \multicolumn{4}{|l|}{ Serum } \\
\hline $\begin{array}{l}\text { Pentosidine } \\
\text { (nmol/l) }\end{array}$ & $155.0 \pm 20.9$ & $97.7 \pm 4.0$ & 0.03 \\
\hline$C R P(n g / m l)$ & $41.8 \pm 6.1$ & - & - \\
\hline $\operatorname{ESR}\left(1^{\text {st }}\right.$ hour $)$ & $38.1 \pm 4.1$ & - & - \\
\hline COMP $(\mu g / m l)$ & $3.5 \pm 0.1$ & $3.3 \pm 0.2$ & NS \\
\hline $\begin{array}{l}\text { Anti-CCP } \\
\text { (positive/negative) }\end{array}$ & $38 / 62 \%$ & $0 / 100 \%$ & $<0.001$ \\
\hline \multicolumn{4}{|l|}{ Synovial fluid } \\
\hline $\begin{array}{l}\text { Pentosidine } \\
\text { (nmol/l) }\end{array}$ & $85.4 \pm 11.3$ & - & - \\
\hline Leukocyte count & $6865.8 \pm 1083.9$ & - & - \\
\hline COMP $(\mu g / m l)$ & $23.8 \pm 2.5$ & - & - \\
\hline
\end{tabular}

DAS, disease activity score; $\mathrm{HAQ}$, health assessment questionnaire; CRP, C-reactive protein; ESR, erythrocyte sedimentation rate; COMP, cartilage oligomeric matrix protein; CCP, cyclic citrullinated peptide.

fluorescent detection. The method developed in our laboratory is based on reversed phase HPLC using Shimadzu HPLC system (model: LC 10ADvp; Kyoto, Japan) operated by CLASS VP software, gradient flow of mobile phase and sensitive fluorescent detection $\left(\lambda_{\text {excitation/ }}\right.$ emission $=335 / 385 \mathrm{~nm}$ ). The separation was performed using compact glass column CGC Separon SGX C18 packed with spherical silica gel particles (with diameter $7 \mu \mathrm{m}$ ) embedded with C18 (octadacyl) group, sized 150x3 mm (Tessek, Prague, Czech Republic); mobile phase (degassed with helium): $0.02 \mathrm{M}$ heptafluorobutyric acid, $0.01 \mathrm{M}\left(\mathrm{NH}_{4}\right)_{2} \mathrm{SO}_{4}$ and linear gradient was given by a variable concentration of acetonitrile (12.5-25\% ACN within $20 \mathrm{~min}$ ), column temperature was $40{ }^{\circ} \mathrm{C}$, flow rate $0.5 \mathrm{ml} / \mathrm{min}$ and time of HPLC run about $30 \mathrm{~min}$, injection $10 \mu \mathrm{l}$. Reproducibility of the HPLC determination itself was $98.8 \%$.

Pentosidine synthetic standard was prepared in our laboratory by modification of the procedure provided kindly by Prof. V. M. Monnier (Case Western Reserve University, Cleveland, OH, USA). Pentosidine standard was synthesized by direct non-enzymatic reaction of carbohydrates with amino acids using poly-L-lysine (hydrobromide), D-ribose, $\mathrm{N}-\alpha$-acetyl arginine, and DETEPAC (a chelate complex former) (Sell and Monnier 1989). Sample pretreatment included acid hydrolysis (in aliquot of $12 \mathrm{M} \mathrm{HCl}$ ), purification and preconcentration by solid phase extraction, vacuum evaporation of excessive solvents using SpeedVac (Savant, USA) and reconstitution in the mobile phase prior to injection into HPLC.

\section{ELISA}

COMP levels were analyzed with a new sandwich ELISA, employing two monoclonal antibodies 17-C10 and 16-F12 that were purified from ascitic fluid by chromatography on a column of immobilized Protein $G$ and concentrated by ultrafiltration. Monoclonal antibody 16-F12 was used as the first (capture) antibody, and biotinylated monoclonal antibody 17-C10 was used as the second (detection) antibody in the assay. The protocol for COMP detection was described earlier (Vilím et al. 2003). Intra- and inter-assay variability was less than $7 \%$ and less than $8 \%$, respectively.

Antibodies directed to citrullinated peptides (anti-CCP) were detected by commercially available ELISA for anti-CCP2 according to the manufacturer's protocol (Immunoscan RA, EuroDiagnostica, Malmoe, Sweden). The results were expressed in $\mathrm{U} / \mathrm{ml}$ with cut-off for normal levels at $25 \mathrm{IU} / \mathrm{ml}$.

\section{Statistical analysis}

Values are expressed as means \pm S.E.M. The Mann-Whitney U-test was used to evaluate statistical significance of difference between two groups. Linear regression analysis was performed to find the relationship between two variables; statistical significance of the correlation was determined by means of the Spearman coefficient. $\mathrm{P}<0.05$ values were considered statistically significant.

\section{Results}

Increased pentosidine levels in patients with rheumatoid arthritis

Pentosidine levels in serum were significantly higher in RA patients than in control individuals 


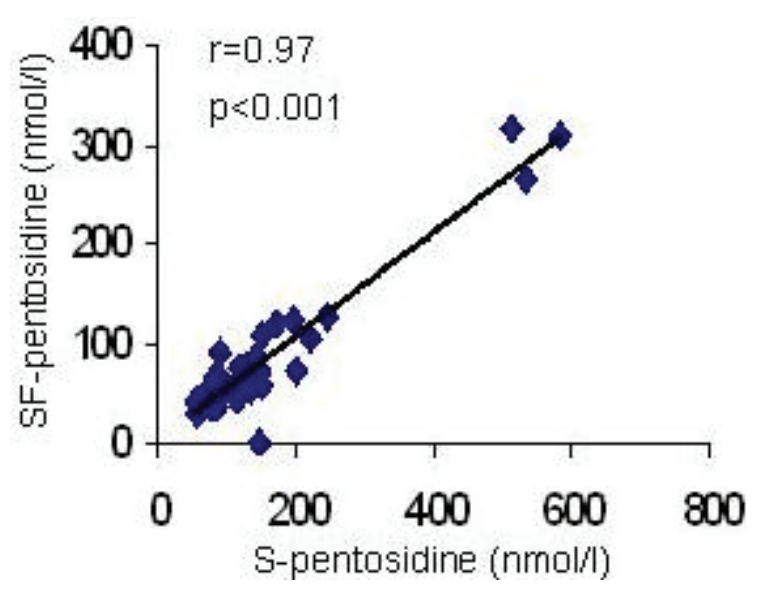

Fig. 1. The levels of pentosidine in serum correlated significantly with that in synovial fluid in patients with rheumatoid arthritis.

$(155.0 \pm 20.9$ vs. $97.7 \pm 4.0 \mathrm{nmol} / \mathrm{l}, \mathrm{p}=0.03)$ (Table 1). Pentosidine was significantly higher in the serum than in synovial fluid $(155.0 \pm 20.9$ vs. $85.4 \pm 11.3 \mathrm{nmol} / 1$, $\mathrm{p}<0.001)$ and the levels in both compartments significantly correlated with each other $(\mathrm{r}=0.97, \mathrm{p}<0.001)$ (Fig. 1). When the levels of pentosidine in both serum and synovial fluid in RA patients were compared with the levels measured in patients with osteoarthritis $(\mathrm{OA})$ in our previous study (Šenolt et al. 2005), surprisingly, only an insignificant increase of pentosidine levels in RA compared to OA was observed (155.0 \pm 20.9 vs. $132.1 \pm 9.2$ $\mathrm{nmol} / \mathrm{l}, \mathrm{p}=0.87$ for the serum and $85.4 \pm 11.3$ vs. $70.7 \pm 3.8$ $\mathrm{nmol} / \mathrm{l}, \mathrm{p}=0.67$ for synovial fluid).

Relationship of pentosidine with the disease activity, functional status, inflammatory markers, cartilage turnover and immune response

All the patients had signs of active disease (mean DAS $28=5.6$ ), however, serum pentosidine levels correlated neither with DAS $28(\mathrm{r}=0.02$, NS) nor with HAQ $(r=0.08$, NS). Pentosidine levels in the serum significantly correlated with ESR $(r=0.44, p<0.03)$ but not with CRP $(r=0.04$, NS). Moreover, pentosidine levels did not correlate with leukocyte counts in the synovial fluid $(r=0.02$, NS). Serum COMP levels $(\mathrm{r}=0.55, \mathrm{p}<0.001)$, but not those in synovial fluid $(r=0.03, N S)$, correlated with age of RA patients. Ageadjusted COMP levels revealed no relationship with pentosidine both in the serum or synovial fluid in RA patients (data not shown). In our study group, more than $60 \%$ of RA patients were anti-CCP negative (less than $25 \mathrm{U} / \mathrm{ml}$ ) and almost $40 \%$ were anti-CCP positive $(51.1 \pm 6.1 \mathrm{U} / \mathrm{ml})$. There was no significant difference between anti-CCP positive and anti-CCP negative groups with respect to serum pentosidine levels $(174.3 \pm 43.5$ vs. $138.7 \pm 24.8 \mathrm{nmol} / \mathrm{l}$, respectively, NS). All subjects from the control group were anti-CCP negative.

Mean duration of the disease in RA patients was 9.6 years and had no significant relationship to the pentosidine levels in the serum $(r=0.15$, NS) or in synovial fluid $(r=0.20$, NS). Pentosidine levels in serum $(r=0.23$, NS $)$ as well as in synovial fluid $(r=0.28$, NS) were not related to the age of RA patients. On the contrary, serum levels of pentosidine in the control group correlated with age of individuals $(\mathrm{r}=0.35, \mathrm{p}=0.03)$. There were no significant differences in pentosidine levels between males and females in both RA and control groups (data not shown).

\section{Discussion}

In this cross-sectional study we have not confirmed previously demonstrated relationship of higher pentosidine levels with clinical disease activity and markers of inflammation in patients with RA. Additionally, no association was observed between pentosidine levels and markers of cartilage turnover or immune response.

Recently, the accumulation of AGE in articular cartilage has been proposed as a molecular mechanism by which aging may predispose to the development of OA (DeGroot et al. 2004). In addition, higher levels of pentosidine in body fluids were described by several research groups in patients with arthritic complaints. We have previously shown that in patients with knee OA higher levels of pentosidine correlated with a marker of cartilage breakdown COMP in synovial fluid as well as with faster radiological progression of the disease (Pavelka et al. 2004, Šenolt et al. 2005). The association of higher levels of pentosidine with the disease status and activity of RA patients was also demonstrated (Takahashi et al. 1997, Miyata et al. 1998, Chen et al. 1998, 1999). Previously we found a positive correlation between pentosidine and COMP in synovial fluid in OA patients (Šenolt et al. 2005), and we explored therefore whether our idea - an association between increased oxidative stress and cartilage breakdown - is also relevant to RA. However, we could not confirm this hypothesis since we did not find any correlation between body fluid levels of pentosidine in RA patients and disease activity status assessed by CRP, DAS 28 or HAQ. In the studies that found positive correlations with pentosidine levels (Takahashi et al. 1997, Chen et al. 1998, 1999), clinical 
activity was measured by different disease activity assessments such as the Lansbury index, which may, at least partially, explain the dissimilar findings. In our study, the erythrocyte sedimentation rate represented the only marker of chronic inflammation that correlated with pentosidine serum levels. Levels of pentosidine in the serum are higher than in the synovial fluid. Thereby, we suggest that systemic circulation represents the main source of pentosidine production that is probably the result of chronic duration of the inflammatory disease, but it is not related to the acute inflammatory response or disease activity.

Comparing the serum and synovial fluid pentosidine levels in RA patients with those levels previously reported by our group in OA patients, we found, unlike others (Takahashi et al. 1997, Chen et al. 1998, 1999), that there is only an insignificant increase of body fluid pentosidine in RA patients. Since the mean age of the OA group was significantly higher, an agerelated increase of pentosidine might be the reason for this increase in OA patients. Previously, it has been shown that AGE can modify IgG and induce persistent IgM anti-IgG-AGE antibody response and can thus play a role in immune response in RA (Lucey et al. 2000, Newkirk et al. 2003, Hein et al. 2004). The latter authors demonstrated that there is an association between serum pentosidine and pro-inflammatory cytokine IL-6 in patients with RA. Moreover, they found a higher synovial fluid pentosidine in rheumatoid factor positive patients than in those with a negative rheumatoid factor. Consequently, we explored a putative association between pentosidine and anti-CCP antibodies - a specific marker for the diagnosis and prognosis of RA. Despite the fact that anti-CCP positive patients tended to have higher serum levels of pentosidine, the difference between anti-CCP positive and anti-CCP negative patients with respect to pentosidne levels was not significant. According to our results, there is no clear association between pentosidine levels and anti-CCP antibodies as a marker of immune response.

In conclusion, our study does not support the idea that pentosidine represents a valuable marker of disease activity in patients with RA. Moreover, no relationship between pentosidine and markers of cartilage breakdown or immune response could be demonstrated. However, it has been recently shown that advanced glycation end-products can modulate the behavior of synovial fibroblasts and chondrocytes, activate MAP kinase ERK and NF- $\kappa \mathrm{B}$, and to stimulate the production of some MMPs (Loeser et al. 2005, Steenvoorden et al. 2006). Thus, advanced glycation could contribute to the joint destruction during chronic rheumatic diseases in situ, which disclose a new paradigm for future research.

\section{Acknowledgements}

We thank Dr. V. Vilím and M. Horáčková for the analysis of COMP. This study was supported by the Czech Ministry of Health (Research Project NR/7895-3).

\begin{abstract}
Abbreviations
RA, rheumatoid arthritis; OA, osteoarthritis; AGE, advanced glycation end-products; COMP, cartilage oligomeric matrix protein; CRP, C-reactive protein; DAS 28, Disease Activity Score 28; HAQ, Health Assessment Questionnaire; HPLC, high performance liquid chromatography; ELISA, enzyme-linked immunosorbent assay.
\end{abstract}

\section{References}

ARNETT FC, EDWORTHY SM, BLOCH DA, MCSHANE DJ, FRIES JF, COOPER NS, HEALEY LA, KAPLAN SR, LIANG MH, LUTHRA HS: The American Rheumatism Association 1987 Revised criteria for the classification of rheumatoid arthritis. Arthritis Rheum 31: 315-324, 1988.

CHEN JR, TAKAHASHI M, SUZUKI M, KUSHIDA K, MIYAMOTO S, INOUE T: Pentosidine in synovial fluid in osteoarthritis and rheumatoid arthritis: relationship with disease activity in rheumatoid arthritis. $J$ Rheumatol 25: 2440-2444, 1998.

CHEN JR, TAKAHASHI M, SUZUKI M, KUSHIDA K, MIYAMOTO S, INOUE T: Comparison of the concentrations of pentosidine in the synovial fluid, serum and urine of patients with rheumatoid arthritis and osteoarthritis. Rheumatology (Oxford) 38: 1275-1278, 1999.

CRNKIC M, MANSSON B, LARSSON L, GEBOREK P, HEINEGARD D, SAXNE T: Serum cartilage oligomeric matrix protein (COMP) decreases in rheumatoid arthritis patients treated with infliximab or etanercept. Arthritis Res Ther 5: R181-185, 2003. 
DEGROOT J, VERZIJL N, WENTING-VAN WIJK MJ, JACOBS KM, VAN EL B, VAN ROERMUND PM, BANK RA, BIJLSMA JW, TEKOPPELE JM, LAFEBER FP: Accumulation of advanced glycation end products as a molecular mechanism for aging as a risk factor in osteoarthritis. Arthritis Rheum 50: 1207-1215, 2004.

DRINDA S, FRANKE S, CANET CC, PETROW P, BRAUER R, HUTTICH C, STEIN G, HEIN G: Identification of the advanced glycation end products $\mathrm{N}$ (epsilon)-carboxymethyllysine in the synovial tissue of patients with rheumatoid arthritis. Ann Rheum Dis 61: 488-492, 2002.

DYER DG, DUNN JA, THORPE SR, BAILIE KE, LYONS TJ, MCCANCE DR, BAYNES JW: Accumulation of Maillard reaction products in skin collagen in diabetes and aging. J Clin Invest 91: 2463-2469, 1993.

FORSLIND K, EBERHARDT K, JONSSON A, SAXNE T: Increased serum concentrations of cartilage oligomeric matrix protein. A prognostic marker in early rheumatoid arthritis. Br J Rheumatol 31: 593-598, 1992.

HEIN GE, KOHLER M, OELZNER P, STEIN G, FRANKE S: The advanced glycation end product pentosidine correlates to IL-6 and other relevant inflammatory markers in rheumatoid arthritis. Rheumatol Int 26: 137-141, 2004.

HITCHON CA, EL-GABALAWY HS: Oxidation in rheumatoid arthritis. Arthritis Res Ther 6: 265-278, 2004.

KAROUZAKIS E, NEIDHART M, GAY RE, GAY S: Molecular and cellular basis of rheumatoid joint destruction. Immunol Lett 106: 8-13, 2006.

LOESER RF, YAMMANI RR, CARLSON CS, CHEN H, COLE A, IM HJ, BURSCH LS, YAN SD: Articular chondrocytes express the receptor for advanced glycation end products: Potential role in osteoarthritis. Arthritis Rheum 52: 2376-2385, 2005.

LUCEY MD, NEWKIRK MM, NEVILLE C, LEPAGE K, FORTIN PR: Association between IgM response to IgG damaged by glyoxidation and disease activity in rheumatoid arthritis. $J$ Rheumatol 27: 319-323, 2000.

MIYATA T, UEDA Y, SHINZATO T, IIDA Y, TANAKA S, KUROKAWA K, VAN YPERSELE DE STRIHOU C, MAEDA K: Accumulation of albumin-linked and free-form pentosidine in the circulation of uremic patients with end-stage renal failure: renal implications in the pathophysiology of pentosidine. $J$ Am Soc Nephrol 7: 1198-1206, 1996.

MIYATA T, ISHIGURO N, YASUDA Y, ITO T, NANGAKU M, IWATA H, KUROKAWA K: Increased pentosidine, an advanced glycation end product, in plasma and synovial fluid from patients with rheumatoid arthritis and its relation with inflammatory markers. Biochem Biophys Res Commun 244: 45-49, 1998.

MONNIER VM, SELL DR, NAGARAJ RH, MIYATA S, GRANDHEE S, ODETTI P, IBRAHIM SA: Maillard reaction-mediated molecular damage to extracellular matrix and other tissue proteins in diabetes, aging, and uremia. Diabetes 41: 36-41, 1992.

NEIDHART M, HAUSER N, PAULSSON M, DICESARE PE, MICHEL BA, HAUSELMANN HJ: Small fragments of cartilage oligomeric matrix protein in synovial fluid and serum as markers for cartilage degradation. $\mathrm{Br} J$ Rheumatol 36: 1151-1160, 1997.

NEWKIRK MM, GOLDBACH-MANSKY R, LEE J, HOXWORTH J, MCCOY A, YARBORO C, KLIPPEL J, ELGABALAWY HS: Advanced glycation end-product (AGE)-damaged IgG and IgM autoantibodies to IgGAGE in patients with early synovitis. Arthritis Res Ther 5: R82-90, 2003.

PAVELKA K, FOREJTOVÁ S, OLEJÁROVÁ M, GATTEROVÁ J, ŠENOLT L, ŠPAČEK P, BRAUN M, HULEJOVÁ M, ŠTOVÍČKOVÁ J, PAVELKOVÁ A: Hyaluronic acid levels may have predictive value for the progression of knee osteoarthritis. Osteoarthritis Cartilage 12: 277-283, 2004.

PREVOO ML, VAN 'T HOF MA, KUPER HH, VAN LEEUWEN MA, VAN DE PUTTE LB, VAN RIEL PL: Modified disease activity scores that include twenty-eight-joint counts. Development and validation in a prospective longitudinal study of patients with rheumatoid arthritis. Arthritis Rheum 38: 44-48, 1995.

RAMEY DR, RAYNAULD JP, FRIES JF: The health assessment questionnaire 1992: status and review. Arthritis Care Res 5: 119-129, 1992.

RAZA K, BREESE M, NIGHTINGALE P, KUMAR K, POTTER T, CARRUTHERS DM, SITUNAYAKE D, GORDON C, BUCKLEY CD, SALMON M, KITAS GD: Predictive value of antibodies to cyclic citrullinated peptide in patients with very early inflammatory arthritis. J Rheumatol 32: 231-238, 2005.

SELL DR, MONNIER VM: Structure elucidation of a senescence cross-link from human extracellular matrix. Implication of pentoses in the aging process. J Biol Chem 264: 21597-21602, 1989. 
SMITH MA, TANEDA S, RICHEY PL, MIYATA S, YAN SD, STERN D, SAYRE LM, MONNIER VM, PERRY G: Advanced Maillard reaction end products are associated with Alzheimer disease pathology. Proc Natl Acad Sci USA 91: 5710-5714, 1994.

STANCZYK J, OSPELT C, GAY RE, GAY S: Synovial cell activation. Curr Opin Rheumatol 18: 262-267, 2006.

STEENVOORDEN MM, HUIZINGA TW, VERZIJL N, BANK RA, RONDAY HK, LUNING HA, LAFEBER FP, TOES RE, DEGROOT J: Activation of receptor for advanced glycation end products in osteoarthritis leads to increased stimulation of chondrocytes and synoviocytes. Arthritis Rheum 54: 253-263, 2006.

ŠENOLT L, BRAUN M, OLEJÁROVÁ M, FOREJTOVÁ S, GATTEROVÁ J, PAVELKA K: Increased pentosidine, an advanced glycation end product, in serum and synovial fluid from patients with knee osteoarthritis and its relation with cartilage oligomeric matrix protein. Ann Rheum Dis 64: 886-890, 2005.

ŠPAČEK P, ADAM M: HPLC method for pentosidine determination in urine, serum, and tissues as a marker of glycation and oxidation loading of the organism. J Liq Chrom Rel Technol 25: 1807-1820, 2002.

TAKAHASHI M, KUSHIDA K, OHISHI T, KAWANA K, HOSHINO H, UCHIYAMA A, INOUE T: Quantitative analysis of crosslinks pyridinoline and pentosidine in articular cartilage of patients with bone and joint disorders. Arthritis Rheum 37: 724-728, 1994.

TAKAHASHI M, SUZUKI M, KUSHIDA K, MIYAMOTO S, INOUE T: Relationship between pentosidine levels in serum and urine and activity in rheumatoid arthritis. Br J Rheumatol 36: 637-642, 1997.

VENCOVSKÝ J, MACHÁČEK S, ŠEDOVÁ L, KAFKOVÁ J, GATTEROVÁ J, PEŠÁKOVÁ V, RŮŽIČKOVÁ S: Autoantibodies can be prognostic markers of an erosive disease in early rheumatoid arthritis. Ann Rheum Dis 62: 427-430, 2003.

VERZIJL N, DEGROOT J, OLDEHINKEL E, BANK RA, THORPE SR, BAYNES JW, BAYLISS MT, BIJLSMA JW, LAFEBER FP, TEKOPPELE JM: Age-related accumulation of Maillard reaction products in human articular cartilage collagen. Biochem J 350: 381-387, 2000.

VERZIJL N, BANK RA, TEKOPPELE JM, DEGROOT J: AGEing and osteoarthritis: a different perspective. Curr Opin Rheumatol 15: 616-622, 2003.

VILÍM V, VOBURKA Z, VYTÁŠEK R, ŠENOLT L, TCHETVERIKOV I, KRAUS VB, PAVELKA K: Monoclonal antibodies to human cartilage oligomeric matrix protein: epitope mapping and characterization of sandwich ELISA. Clin Chim Acta 328: 59-69, 2003.

\section{Corresponding author}

L. Šenolt, Institute of Rheumatology, Na Slupi 4, 12850 Prague 2, Czech Republic. Fax: +420 224914451. E-mail: seno@revma.cz 